\title{
IMPROVING STUDENTS' READING COMPREHENSION BY USING PEER ASSISTED LEARNING STRATEGIES (PALS) IN EFL CONTEXTS
}

\author{
Sulistami, $\mathrm{P}$. \\ Sultan Ageng Tirtayasa University \\ Puput010191@gmail.com \\ Pahamzah, J. \\ Sultan Ageng Tirtayasa University \\ johnpahamzah@untirta.ac.id \\ Baratayaomi,W. \\ Sultan Ageng Tirtayasa University \\ wiekabaratayaomi@untirta.ac.id \\ Syafriza, S. \\ Sultan Ageng Tirtayasa University \\ syafrizal@untirta.ac.id
}

\begin{abstract}
This research is aimed to describing the process of teaching reading comprehension and identifying whether Peer Assisted Learning Strategies (PALS) can improve students' reading comprehension at the tenth grade of SMA Negeri 6 Kota Serang. The subject of this research was 30 students in Class X IPS 2. While doing Classroom Action Research (CAR), the researcher was helped by the English teacher as collaborator to observing the research and to know the process of teaching reading comprehension through PALS. The significant improvement of reading comprehension showed from result of pre-test and post-test. The Minimal Mastery Criteria (MMC) score in SMAN 6 Kota Serang in English subject was 75. In the pre-test the average score of students' was 45.6 and there were only 2 students $(6.7 \%)$ who passed MMC. In the post-test of cycle I, the average score of students' was 69.57 with 12 students (40\%) who passed the KKM. The average score of students' post-test II was 83.3 and there were 26 Students (86.6\%) who passed MMC. In conclusion, the student's reading comprehension was improved and the students were able to comprehend the text through PALS.
\end{abstract}

Keywords: reading comprehension, Peer Assisted Learning Strategies (PALS), Narrative Text, Classroom Action Research (CAR)

\section{INTRODUCTION}

Reading is one of important things in English language teaching and become one of ability which should be mastered by students. This statement supported by Brown (2001: 232) that says English language teaching has identified "four skills" - listening, speaking, reading, and writing - as of paramount importance. Reading as one of the four skills of listening, speaking, reading, and writing has always formed part of the syllabus in teaching of English. It means that reading is a basic skill in teaching and learning English. It must be mastered by learners in order to make their able to get more information and knowledge. Wallace (1993: 4) defines reading as interpreting means reacting to a written text as a piece of communication. It means that reading is a process to get some information and knowledge from the written text that becomes a way of communication. It is not only simple process of getting information from the text but also the process of thinking to understand the content of the text.

Based on researcher found when doing teaching field experience at SMA Negeri 6 Kota Serang, the researcher found that students have some difficulties in English, especially in reading comprehension. Many students are not good enough in reading comprehension, still difficult to understand the main idea or the content of the text, they are lack of vocabulary, and low in grammatical structure. Besides that 
problem, there are some another factors that make students still have low ability in reading comprehension. One of them is, the teacher does not use any method in teaching reading and let the students read alone and then do the task or the worksheet. The teacher rarely, gives students opportunity to read a text alone with guiding by the teacher. To solve those problems, the teacher can use some strategy that can improve students' reading comprehension. The researcher proposes the teacher to use one kind of peer tutoring strategies that is Peer Assisted Learning Strategies (PALS). To dig deeper about the reserach, the researcher made the question of reserach: (1) how is the process of implementation of Peer Assisted LearningStrategies (PALS) in improving students' reading comprehension?; (2) how is the improvement of students reading comprehension by using Peer Assisted Learning Strategies (PALS)?

\section{Reading}

Reading is one of skill that have to be mastered by students that need a process. By reading students can understand the content of a text and the meaning that shared by the writer. That statement in the line with Tarigan (2004: 4) says, reading is active process in which reader shift between source of information (what they know and what the text say), elaborate meaning and strategies check their interpretation (revising when appropriate), and use the social context to focus their response. It means that, with reading the readers can express their opinion about the content of the text, based on their background knowledge and experience. Moreover, reading also can build reader's critical thingking toward an a context of a text.

According to Grabe and Stoller (2002: 9) reading is the ability to draw meaning from the printed page and interpret the information appropiatetely. That statement can be interpreted that reading is a ability where the readers can get the main idea in a printed text and than developed the information that they get..

\section{Peer Assisted Learning Strategies (PALS)}

Peer Assisted Learning Strategies (PAL/ PALS) is a strategy when the learning process more active with asking students to teach other students during the learning. Interventions effectively engage students in the learning process and produce academic gains across a variety of student populations, academic subjects, and classroom arrangements (Johnson et al, 1981 cited in Rohrbeck, 2003: 240).

Peer Assisted Learning Strategies (PALS) is a scheme that fosters cross-year support between students on the same course. PALS encourage students to support each other and to learn co-operatively under the guidance of students from the year above. People (students), who are not professional teachers, help and support the learning process of others, in an interactive, purposeful and systematic way (Topping, 2009: 2).

\section{Features of Teaching Reading through Peer Assisted Learning Strategies (PALS)}

PALS incorporate several important features. First, all students in a class are paired. Second, students are trained to use specific prompts, corrections, and feedback. Third, PALS incorporates frequent verbal interactions between tutors and tutees, increasing students' opportunities to respond (Greenwood et al., 1989 in Fuchs \& Fuchs, 2006: 8). Fourth, roles are reciprocal, so that both students in a pair serve as tutor and tutee during each session. Fifth, PALS consists of a set of structured activities, and students are trained to implement them independently.

These activities include Partner Reading with Retell, Paragraph Shrinking, and Prediction Relay. Teachers use a set of brief scripted lessons to train all students. The training lessons for each activity last thirty to sixty minutes per session and take two to three sessions to implement. These lessons include scripted teacher presentations, student practice, and teacher feedback.

\section{Activities of Teaching Reading though Peer Assisted Learning Strategies (PALS) a. Partner Reading and Retelling.}

Each student reads aloud from connected text for five minutes each. This text comes from the literature selected by the teacher and should be at an appropriate level for the lower-performing student in each pair. The higher-performer reads first, then the lower-performer reads the same text. Whenever the reader makes an error, the tutor says, "Stop, you missed that word. Can you figure it out?" If the reader does not figure out the word in four seconds, the tutor says, "That word is - . What word?" The reader says the word and continues reading. After both students have read, the lower-performing student retells 
the sequence of events just read for two minutes. Students earn one point for each sentence read correctly, and ten points for the retell.

\section{b. Paragraph Shrinking}

This activity is designed to develop comprehension through summarization and main idea identification. Students use a questioning strategy to direct their attention to the important ideas or events they are reading about (e.g., Jenkins et al., 1987 cited in Fuchs \& Fuchs 2006: 9). During Paragraph Shrinking, the students continue reading orally, but they stop at the end of each paragraph to identify the main idea. The tutor asks the reader to identify who or what the paragraph is mainly about, and the most important thing about the "who" or "what". The reader must condense, or "shrink," this information into ten words or fewer. If the tutor determines that the reader's answer is incorrect, she says, "That's not quite right. Skim the paragraph and try again." After the reader provides a new answer, the tutor decides whether the answer is correct. If the tutor determines that the answer is incorrect, she provides a correct answer, and the pair continues reading. After five minutes, the partners switch roles.

\section{c. Prediction Relay}

In this activity, requires students to make predictions and then confirm or disconfirm them. This activity is included in PALS because making predictions is a strategy associated with improvements in reading comprehension (Palincsar\& Brown, 1984 cited in Funch\&Funch, 2006: 10). Prediction Relay consists of four steps: the reader makes a prediction about what will happen on the next half page to be read, reads the half page aloud, confirms or disconfirms the prediction, and summarizes the main idea. If the tutor disagrees with the prediction, she says, "I don't agree. Think of a better prediction". Students earn points for each reasonable prediction, for reading each half page, for accurately confirming or disconfirming the prediction, and for identifying the main idea in ten words or fewer. Again, the students switch roles after five minutes.

\section{Previous Study}

There is a previous study that talk about the effect of peer tutoring in improving reading comprehension, entitled "The effects of a peer tutoring program to improve the reading comprehension competence involving primary students at school and their families at home" which is conduct by Silvia Blanch at al. at University of Barcelona in Catalunya, Spain.

That paper presents on the effects of an educational program involving peer tutoring at school and family tutoring at home on child reading comprehension achievement. The researcher drew upon a sample of 303 students and 223 family tutors. The methodology combined a quasi-experimental design and a qualitative analysis of texts. Background variables were collected by means of student and parent questionnaires and also teacher and family interviews. An analysis of the family tutoring interactions was also monitored. Overall, the study reveals the effectiveness of peer learning to improve reading comprehension skills and the potential of family involvement for the development of academic skills.

\section{METHODS}

The researcher used qualitative and quantitative approach as the way to answer the research question, and this research has done through Classroom Action Research (CAR) design. CAR was one of problem solving that has function to improve the quality of teaching and learning process in class room done by the teacher, collaborator and students. Altrichter et al (2008:9) defines that, action research is a cyclical or spiraling process "that integrates theory with practice, through reflection and action planning". The process includes a series of steps including posing a question, collecting and analyzing data, and reporting findings.

Moreover, the researcher investigated the use of strategy to improve reading's comprehension where the researcher acted as teacher, the teacher acted as collaborator, and the students acted as object to implement Peer Assisted Learning Strategies (PALS) in improving students reading skill in narrative text.

The researcher was conducted the research at SMA Negeri 6 Kota Serang and choose class X IPS 2 which consists of 30 students as a subject of the research. The researcher chose that class because the students in X IPS 2 had difficulties and problem in reading comprehension when the researcher did the 
teaching practical understanding (PPLK). So, the researcher wants to improve students' reading comprehension by using Peer Assisted Learning Strategies (PALS).

The research procedure that used in this research is based on the procedure on Classroom Action Research (CAR). The design of action research was consisted of two cycle which are related and continuity. There are four activities that have been done in this design for each cycle. According to Kemmis and McTaggart (2014: 8) action research occurs through a dynamic and complementary process, with consists of four essential 'moments': of planning, action, observation and reflection.

The researcher used the procedure of research as follow:

1. The researcher chose one class to be observed about the students' reading skill

2. The researcher was conducted the process of teaching learning process step by step by using Peer Assisted Learning Strategies (PALS) method to improve students' reading skill.

3. The researcher used Classroom Action Research by doing cycles. At least there are two cycles that was conducted, and each cycle consisted of two meeting in order to improve students' reading skill.

The researcher was conducted the design consisted of two cycles which each cycle consist of two meetings. These cycles related each other and continuity. Based on Kemmis\&McTaggrat (2014: 9), action research occurs through a dynamic and complementary process, with consist of four essential 'moments': of planning, action, observation and reflection.

\section{Planning}

The researcher should plan what will teach to the students. The researcher provides the lesson plan, the material, the media, included the pre-test and pos-test.

\section{Action}

The researcher did the activities that have planned before. In this research the researcher was conducted Peer Assisted Learning Strategies (PALS) in the class in order to improve student's reading comprehension with using narrative text.

\section{Observation}

In this step, the collaborator sees and observed during the teaching reading by using of Peer Assisted Learning Strategies (PALS) that apply.

\section{Reflection}

Reflection is step when the researcher and collaborator reflected, evaluated and described the effect of action. It purposes to know the effectiveness of learning process and to find out the weakness, then the researcher could do further cycle in action research to improve the result of previous result.

The instruments that used in this research are test, both pre-test and post-test. Besides that, the research also used observation as the instruments.

\section{Test}

The researcher conducted the pre-test before doing the treatment. The pre-test was conducted to choose the students who would be a tutor for the other students and also to find out the background knowledge and reading comprehension of students. After the treatment, there is a post test that conduct to find out did the peer tutoring method effective to improve students' reading comprehension. The post-test was conducted twice. The first post-test conducted after the first treatment (in cycle 1) have done to see the imrpovement. The second post-test conducted after doing the second treatment (cycle 2) and after did the reflection of the cycle 1 .

The test both the pre-test and post-test used written test, which consists of two parts and the test was held in 90 minutes. The question of the test was divided into two parts. The part A consist of 15 questions of multiple choices, where each number has 4 point. Than, part B consist of 5 simple answers question, which each number has 8 point.

\section{Observation}

The researcher used direct observation as the instrument of the research. The researcher asked the teacher as collaborator to doing the observation toward the teaching learning process. The teacher took a note in the observation sheet, during the process of teaching learning by using Peer Assisted Learning Strategies (PALS). The teacher as collaborator observed did the student has running her/his act as tutor and tutee. Based on the procedure and activity that do in PALS in teaching reading comprehension. 
The data has collected through qualitative and quantitative method. The researcher collected the data from the observation sheet as resource of qualitative data, used the pre-test and post-test to gather the data as resource of quantitative data.

\section{FINDING AND DISCUSSION Finding}

The researcher conducted some pre-test to recheck and to know the students' background knowledge in reading comprehension, especially in Narrative text material. The pre-test was conducted on Tuesday, April $03^{\text {rd }} 2018$. The result of the pre-test was used as base score and also as standard to determine whose would be the tutor and whose would be a tutee (students). Half students who got the higher score become the tutor and the rest half students who got lower score acted as tutee. The data of pre-test (see appendix) showed that most of students were having poor reading comprehension. It was proved from the average of students' score of pre-test was very low and almost all students did not pass the KKM of English subject. From those problems, the researcher encouraged to improve students' reading comprehension in narrative text by using Peer Assisted Learning Strategies (PALS).

The researcher designed this research in six meetings. The meeting was divided in to two cycles. Each cycle consisted of three meeting, two meeting for treatment and one meeting for post-test. At cycle one, the topic of narrative that used is understanding the generic structure and identifying narrative text about legend and folktale. Meanwhile, in cycle two the topic was about understanding and identifying narrative text about legend and folktale that the content was more than before. In the end of each cycle, students did post-test. Where, the result of post-test from first cycle compared with the pre-test. The, the result of post-test in cycle two compared with the result of post-test in cycle one.

The researcher had done the Classroom Action Research at the tenth grade students of SMA Negeri 6 Kota Serang in academic years 2017/2018. It was done in one class (X IPS 2) in second term. It was consisted of two cycles which each cycle consisted of tree meeting, two meeting for treatment and one meeting for conducted post-test. It took two cycles because from the process of pre-test, cycle II, cycle II, the students' problems in teaching reading had been solved. It was supported by the result of pre-test score, post-test score in cycle I, and post-test score in cycle II that had improvement and the score was above the Minimum Mastery Criteria.

It was proven by the target in this researcher was reached where the students average score of reading comprehension should above the standard of Minimal Mastery Criteria in that school.

To know the background knowledge of students about reading comprehension, the researcher gave pre-test before doing the treatment. The result of pre-test was far from the standard Minimal Mastery Criteria in that school. The result of pre-test was 43.6 (see Appendix III), whereas score Minimal Mastery Criteria for English was 75. The frequency of student' who passed the KKM was $6.7 \%$ because, there just 2 students who passed the test. Therefore, the researcher concluded that most of students need to improve reading comprehension. It was influenced by the problems that happened, such as the students did not interested in reading, taught that reading a text was bored, and lazy to read because did not have desire on it. Students also have problem in comprehending the information from the text, because they were lack in vocabulary.

In cycle I, those problems still appeared in teaching and learning process. Students have difficulties in comprehending a text or the questions that asked and they seem did not have any desire to read English text. When the researcher explained materials about Narrative text, some of students were busy with their own activities, and the rest looked passive. They looked shy and afraid of made mistake. To running the exercise, the researcher explained carefully the steps of implementing Peer Assisted Learning Strategies (PALS) to the students. It was started by implementing Partner Reading and retelling activity. At the beginning, students were difficult to pay attention to the teacher because some of them was joking and chatting with the others. The students also looked confuse to the researcher explanation and looked passive and keep silent. Then, paragraph shrinking activity. This activity was very helpful for students to make students comprehend the text and understanding the context of the text. Although, some tutee still confused and needed the tutor direction in made the summary and found the main idea. In the next activity prediction relay, the tutee could not make a right prediction. After the tutor direct and help them, the tutee started to understand to made a right prediction. Prediction relay activity was helpful for students to improve their vocabulary and to comprehend the text. 
The result of students' post-test in cycle I was 69.57 (see Appendix IV), and there are 12 students who passed test (40\%). It was improve 26.1 points from the pre-test result. Although the score improved from the pre-test, but it was still under the standard Minimal Mastery Criteria in that school.

Before doing the cycle II, the researcher and the collaborator collected the data from the test and observation sheet. Then, they evaluated and analyzed together the data and the process of teaching to know the weaknesses in cycle I. The researcher tried to be solved the weaknesses in cycle I, by more prepared anything to which can improve the teaching learning process. The researcher revised the lesson plan with developing the activities, format of evaluation and developing the material. The materials were focus on students' needs based on the students answer in every exercise and test. The material were about understanding the text, found the main idea, $5 \mathrm{~W}+1 \mathrm{H}$ question, and draw the moral value that can got from the text. In process of teaching learning, the students, the students were pay attention to the researcher's explanation and gave good responses to the teacher. They could ask any question about the material and seems very active. In running their jobs, students who acted as tutor or the tutee can work cooperatively in pairing team. The tutee can did all activities in PALS well, even few tutee still have difficulties in prediction relay and need help by the tutor. The tutor also was able to run his jobs as tutor well. The tutor could help and direct the tutee to did the all activities in PALS of reading comprehension. The teaching reading through PALS ran well because the students could do their own roles as tutor and tutee. It was helpful to students in comprehending a text. The result of average score students' post-test in cycle II was 83.30 (see Appendix V). It was improved 13.5 points, from the result of students' average score of post-test in cycle I. in this test, there were 26 (86.6\%) students who passed the Minimal Mastery Criteria.

Table 1. Students' Reading Comprehension Improvement

\begin{tabular}{|c|c|c|}
\hline TEST & AVERAGE SCORE & IMPROVEMENT \\
\hline PE-TEST & 43.60 & - \\
\hline POST-TEST I & 69.75 & $26.1 \%$ \\
\hline POST-TEST II & 83.30 & $13.5 \%$ \\
\hline
\end{tabular}

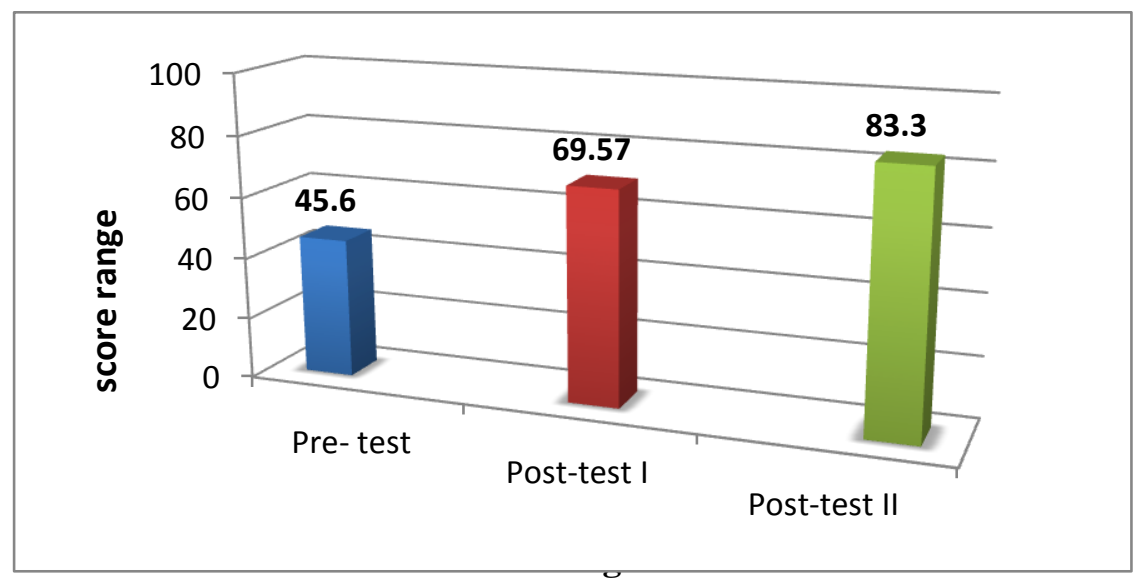

Figure 1.Students' Reading Comprehension Improvement 


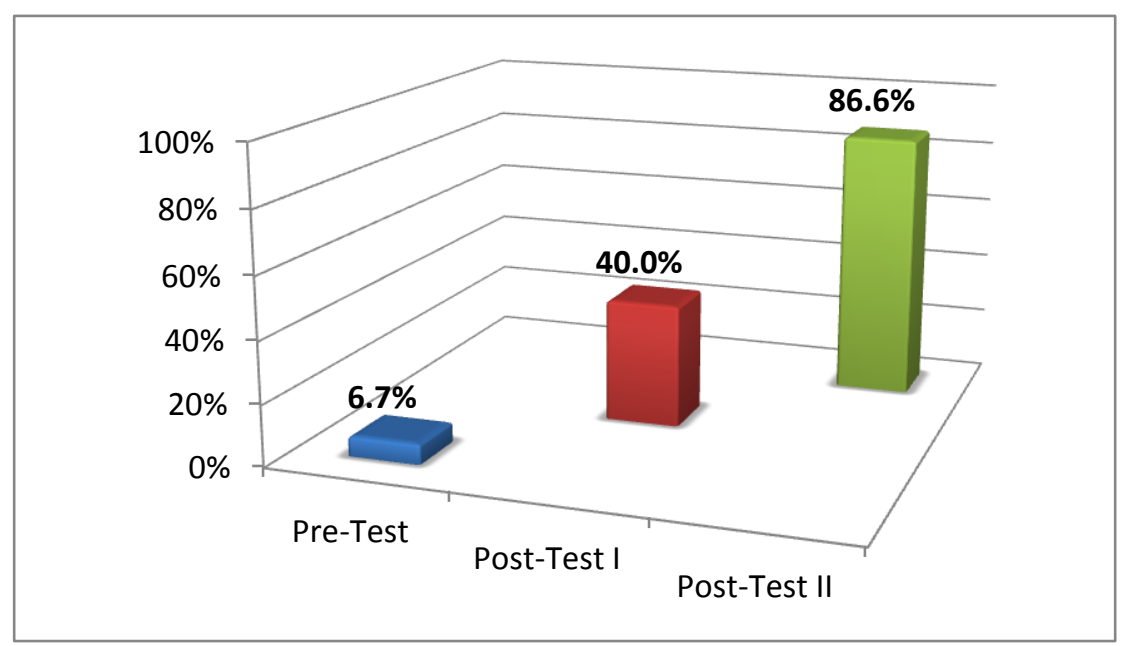

Figure 2. Percentage of Students' Frequency Who Passed MMC Improvement

Based on the description above, it can be concluded that there was an improvement in students' score. The improvement started from the post-test I in cycle I. The average score of post-test I was better than the pre-test score, and the average score of post-test II in Cycle II was better than post-test I. And almost of the students are achieved score of Minimal Mastery Criteria (MMC).

Based on the data above, proven that Peer Assisted Learning Strategies (PALS) can improve students comprehension, especially in narrative text. Students' ability in comprehending narrative that was improved, it showed from the students' average score that improved and also from the students' behavior in teaching learning process after the classroom action research have done.

In implementing PALS, the students not only improve their reading comprehension on narrative text, but also it increased their skill of pronunciation, summarized a text, and understanding the question which usually appeared in reading test. In doing the cycles, the students felt enjoy and enthusiastic to the materials. It was because the researcher chose the interesting material of narrative text, and the students felt more comfort and free to told their opinions and showed their mistakes to the peer. The students were more active in teaching learning during the process PALS of reading comprehension. They asked some question related to materials, the steps and duty of tutor or tutee of implementing PALS.

In conclusion, improving students reading comprehension in narrative text by using PALS was able implemented at the tenth grade of SMA Negeri 6 Kota Serang. So, the cycle of CAR did not have to be continued.

\section{CONCLUSION}

Based on the result and discussion of the research, teaching reading comprehension in narrative text by using Peer Assisted Learning Strategies (PALS) could improve the average score of students' reading comprehension in one class of tenth grade students of SMA Negeri 6 Kota Serang. This strategy could be used as way to teach in reading class especially in learning narrative text. Moreover, Peer Assisted Learning Strategies (PALS) could help the students the text well. It could be seen from the students' progress in test and in every meeting. There is significant improvement that showed in this research, it proved from the improvement of the average students' score and students who passed the KKM. In the pre-test the students' average score was 45.6 and the frequency of students who passed the KKM was $6.7 \%$ ( 2 students). In the post test I of cycle I, the students' average score improved into 69.57 with frequency of students who passed the KKM was $40 \%$ (12 Students). In the post test II of cycle II, the average students' score was improved again into 83.3 with frequency of students who passed the KKM was $86.6 \%$ (26 Students).

Based on the result of research, the research concluded that teaching reading comprehension through Peer Assisted Learning Strategies (PALS) was successful and could implemented in teaching reading, especially narrative text. It was effective to improve students' reading comprehension.

Based on the conclusion above, the researcher would like to suggest to other teacher to used Peer Assisted Learning Strategies (PALS) in teaching reading comprehension especially in narrative text. 
PALS can used to improve students' reading comprehension. It was because all steps of PALS is really helpful in comprehending a text well and made the students more active and enthusiastic in joining the reading class. The teacher has to explain the PALS slowly so, the students would understand. Besides, the students should know the most appropriate learning strategy that can be used especially in English subject. One of strategy that can use in learning reading comprehension is Peer Assisted Learning Strategies (PALS). The students can use PALS narrative text to improve their reading comprehension. The researcher hope that Peer Assisted Learning Strategies (PALS) can became references to who are interested with peer tutoring or Peer Assisted Learning Strategies (PALS). So, the researcher perhaps this research will beneficial to other researcher in finding references.

\section{REFERENCES}

Arrand, K. (2014). Peer Tutoring; Journal of Pedagogy Development. Luton Bedford: Centre for Learning Excellent. Available at https://www.beds.ac.uk/jpd/volume-4-issue-1/peer-tutoring.

Arikunto, S. (2012). ProsedurPenelitian. Jakarta: Pt. RinekaCipta.

Brown, H.D. (2001). Teaching by Principles: An Interactive Approach to Language Pedagogy Second Edition. New York: Addision Wesley Longman.

Falchikov, N. (2002). Learning Together; Peer tutoring in Higher Education. RoutledgeFalmer. New York.

Funch, D. Funch L. S \&Mathes, P. G. (1997) Peer-Assisted Learning Strategies: Making Classrooms More Resvonsive to Diversity. American Educational Research Journal. 34-174

Fuchs, D. Fuchs L. S \&Burish P. (2000). Peer-Assisted Learning Strategies: An empirically-supported practice to promote reading achievement. Learning Disabilities Research and Practice. 15, 85-91.

Funch, D. Funch L. S \& Saenz L. M. (2005) Peer-Assisted Learning Strategies: for English Language Learners with Learning Disabilities. Council for Exceptional Children. 231-247.

Fuchs, D \& Fuchs, L.S. (2006). Research on Peer-Assisted Learning Strategies: The Promise And Limitations of Peer-Mediated Instruction; Reading \& Writing Quarterly vol. 22 p.5-25.

Grabe, W \&Stoller, L.F. (2002). Teaching and Researching Reading. London: Pearson Education Longman.

Harmer, J. (2003). How to Teach English: New Edition. London: Pearson Longman.

Hatch, E. \&Farhady, H. (1982). Research Design and Statistic for Applied Linguistics. New York: Library of Cingress Cataloging in Publication Data.

Herdiana. (2016). Improving Students' Reading Comprehension in Recount text through Schema Activation Strategy (SAS) at the Eight Grade of SMPN 18 Kota Serang. UNTIRTA: Serang.

Hott, B \& Walker, J. (2011). Peer Tutoring. Council for Learning Disabilities Journal. Cld International: New Jersey. USA.

Kemmis, S. \&McTaggrat, R. (2014). The Action Research Planner. Victoria: Dakin University Press.

Klinger, et al. (2007). Teaching Reading Comprehension to Students with Learning Difficulties. New York: The Guildford Press.

Maheady, L.H. \&Mallette, B. (2001). Peer-mediated instruction and interventions and students with mild disabilities. Remedial and Special Education, 22.

Miles, M. \&Huberman, M. (1994). Qualitative Data Analysis. London: SAGE.

Ningsih, E. \&Ilzamudin. (2016). Teaching student's Reading Comprehension on Narrative Text Using Peer Tutoring Strategy: ASSES English Education Journal (Vol. 2). The State for Studies Sultan MaulanaHassanudinBanten.

Nuttall, C. (2005). Teaching Reading Skills in a Foreign Language. Oxford, UK: Macmillan Education.

Riduwan. (2012).SkalaPengukuranVariabel-variabelPenelitian. Alfabeta. Bandung

Rohrbeck, A. C. (2003). Peer-Assisted Learning Interventions With Elementary School Students: A Meta-Analytic Review. Journal of Education Psychology. American Psychology Association Inc; America.

Smith, N. B. (2003). Be a Better Reader: Eight Edition. New Jersey: Globe Feuron.

Tarigan, H. G. (2008). MenulisSebagaiSuatuKeterampilanBerbahasa. Bandung: Angkasa.

Topping, K. \&Ehly, S. (2009). Peer Assisted Learning. Routledge: New York.

Wallece, C. Reading. (1993). Oxford: Oxford University Press. 